Hubert Cuyckens

\title{
Reconciling older and newer approaches to grammaticalization
}

https://doi.org/10.1515/gcla-2018-0009

\begin{abstract}
The grammaticalization literature has seen three different strands of grammaticalization research: research inspired (i) by Lehmann's unidirectional reduction view, in which a grammaticalizing item loses integrity and becomes increasingly dependent; (ii) by Himmelmann's context-expansion view; and (iii) research that is integrated into a construction grammar approach to language. With each (new) domain of inquiry seems to have come a distinct set of criteria. This may create the impression that grammaticalization simply adjusts its criteria - in an ad-hoc fashion - to the domain at hand. Informed by the discussion in Traugott and Trousdale (2013), I argue in this paper that what look like distinct sets of grammaticalization criteria may not be as distinct as first meets the eye.
\end{abstract}

Keywords: Grammaticalization as reduction and expansion, Constructional grammaticalization, Grammaticalization criteria, Lehmann, Himmelmann

\section{Introduction}

For more than three decades, grammaticalization has attracted great interest in the domains of (English) historical linguistics and typology. The work by Lehmann (2015 [1995]), the collective volumes by Traugott and Heine (1991), and the handbook by Hopper and Traugott (1993) were crucial in the development of the field. They generated a wealth of case studies applying the parameters of grammaticalization laid out in these seminal works to (largely morphosyntactic) diachronic change and cross-linguistic variation studies (e.g., Bybee et al. 1994; Ramat and Hopper 1998; Fischer et al. 2000). Following up on a number of critical assessments (poignantly voiced in a special issue of Language Sciences [Campbell 2001]), grammaticalization seemed to have found renewed vigor with the publication of a number of volumes emanating from the "New Reflections on Grammaticalization" conferences (Wischer and Diewald 2002; Fischer et al. 2004; Lopez-Couso and Seoane 2008; Seoane and Lopez-Couso 2008; Davidse et al. 2012; Smith et al. 2015); with such important volumes as Bisang et al. (2004), Traugott and Trousdale (2010), and Van linden et al. (2010); with special issues in Language Sciences (Norde et al. 2013; Breban and Kranich 2015) and 
Folia Linguistica (Von Mengden and Simon 2014); with the publication of Heine and Kuteva's World Lexicon of Grammaticalization (2002) and Narrog and Heine's The Handbook of Grammaticalization (2011); and with volumes emanating from the "International Conference on Grammaticalization Theory and Data" (Hancil and König 2014; Hancil et al. forthc.). ${ }^{1}$

When surveying this wealth of grammaticalization studies, it becomes readily apparent that different domains of inquiry have come into focus over the years. A first strand of grammaticalization studies, largely inspired by Lehmann's (2015 [1995]) Thoughts on Grammaticalization, views grammaticalization as unidirectional change towards reduced syntactic, morphological, or phonological forms. ${ }^{2}$ Typical examples are (i) the shift from noun to affix, as in Hungarian haz-ban [house-INESSIVE] 'in the house', where the suffix -ban was once the locative case of the noun 'interior' (see Hopper and Traugott 2003: 111); (ii) the shift from verb to affix, as in Latin dare habes [give.INF have.2sG.PRS.SBJv] > daras 'you will give' (Clackson 2016: 10); (iii) the shift from the lexical verb cunnan to auxiliary can in English (Hopper and Traugott 2003: 55-56); (iv) the change from the English preposition to /tu:/ to the infinitival marker to /tə/ (Haspelmath 1989; Fischer 2000); (v) the shift from partitive noun to quantifier, as in English [a lot [of land] > [a lot of [land]] (Brems 2010, 2011, 2012). In this domain of inquiry, semantic change is, on the whole, given relatively short shrift, ${ }^{3}$ in that reduced, grammaticalized form is said to co-occur with reduced (i.e. bleached, more abstract) meaning. Reacting against the marginal treatment of semantics in grammaticalization studies are Heine et al. (1991), Traugott and König (1991), and especially a series of studies by Elizabeth Traugott (see Traugott 1989, 2003, 2010b; Traugott and Dasher 2002). These studies highlight the role of metaphorical change (Heine) and especially invited inferencing (or conceptual metonymy) and (inter) subjectification in grammaticalization.

As Traugott rightly points out, the requirement of structural reduction and dependence, which characterized this first strand of grammaticalization studies,

1 After the turn of the century, grammaticalization studies also spread out to the generative paradigm; see, for instance Roberts and Roussou 2003; Van Gelderen 2004). We will, however, not be concerned with these studies here.

2 In this respect, Lehmann (2004: 155) defines grammaticalization as "a process in which it loses in autonomy by becoming more subject to the constraints of the linguistic system". Similarly, Haspelmath (2004: 26) views grammaticalization as "a diachronic change by which parts of a constructional schema come to have stronger internal dependencies".

3 Brems's work is the exception here, as she does pay attention to semantic change in grammaticalization. 
limited grammaticalization to "those parts of grammar that may be expressed in languages with inflections" (Traugott 2010a: 276). A second strand of grammaticalization studies, examining on the development of discourse markers such as head. Please confirm. well (Jucker 1997), in fact (Traugott and Dasher 2002), you know (Brinton 1996), epistemic parentheticals such as I think, I guess, I feel (Thompson and Mulac 1991), and connectives such as but (Hancil 2014), may be better served, Traugott argues, by viewing grammaticalization as structural expansion - an approach most clearly articulated by Himmelmann's (2004) three types of context expansion (see below).

More recently, grammaticalization studies have been approached from a more encompassing view, integrating grammaticalization into (Cognitive) Construction Grammar, as initiated, for instance, by Goldberg $(1995,2006)$. On this approach, which has been laid out in most detail in Traugott and Trousdale (2013), grammaticalization is rethought in constructional terms, whereby equal attention is given to changes in form and meaning (see also Barðdal et al. 2015; Coussé et al. 2018).

At first sight, with each (new) domain of inquiry seems to have come a distinct set of criteria: Lehmann's criteria characterizing the reduction view; Himmelmann's context expansion criteria for the expansion view; a different set of criteria still (involving schematicity, productivity, and loss of compositionality) for the constructional approach to grammaticalization. This may create the impression that grammaticalization has become a diluted concept, with ad-hoc criteria for each domain of grammar.

Against this background, I argue, informed by the discussion in Traugott and Trousdale (2013), that there is more correlation between the different sets of criteria than first meets the eye. In other words, the various sets of criteria often pertain to the same phenomena, only from different perspectives. To illustrate this, two-case studies are presented: the development of $a$ lot of from partitive noun to quantifier to degree modifier, as detailed in Brems (2010, 2011, 2012), and the development of the discourse marker in fact, as discussed in Traugott $(1997,1999)$ and in Traugott and Dasher (2002). Rather than present new analyses, this paper emphasizes the importance of finding common ground in the various approaches to grammaticalization.

\section{Lehmann and Himmelmann compared: $a$ lot of}

In this section, I discuss the shift from partitive $a$ lot [of $+\mathrm{N}$ ] to quantifier $a$ lot of/ lots of $+\mathrm{N}$ as a case of grammaticalization in terms of Lehmann's criteria. I then show how these "reduction" criteria correlate with Himmelmann's "expansion" criteria. 
Lehmann (2015 [1995]) distinguishes paradigmatic and syntagmatic criteria, each of which reflect that grammaticalization can be characterized in terms of reduction of the grammaticalizing item, or still, in terms of its increasing dependence or decreasing autonomy. For one, the informal variants alotta and lotsa show loss of phonetic integrity with respect to the full quantifier forms $a$ lot of and lots of (and a fortiori with respect to the partitive noun a lot [of $+\mathrm{N}]$ ); in addition, the form is semantically reduced/bleached, in that the 'share/ part' meaning of the partitive noun has been lost. Second, as the form a lot of/lots of/lotsa grammaticalizes, it shifts from the paradigm of (size/partitive) nouns to that of quantifiers. Size/partitive nouns are members of the large set of nouns, with little cohesion; in contrast, quantifiers make up a much smaller set with a homogeneous function, and therefore show much more cohesion, or higher paradigmaticity. In becoming a member of the paradigm of quantifiers, a lot of/lots of/lotsa increases rather than reduces paradigmatic variability; however, its relative frequency with respect to much/many is likely to have increased over time such that it can be said to have become increasingly obligatory. The development of the quantifier a lot of/lots of/lotsa also meets most of Lehmann's syntagmatic criteria. The criterion syntactic scope (i.e. the structural size of the construction the grammaticalizing items help to form) is satisfied: the partitive noun a lot has scope over the following PP-postmodifier, which constitutes a PP sister node to a lot, whereas the quantifier a lot of/ lots of/lotsa only scopes over the following noun (i.e. the quantifier simply combines with $\mathrm{N}$ under the same NP node). Bondedness applies in that lots has coalesced with of in lotsa, or lot has coalesced with $a$ and of in alotta, disallowing any material from intervening. Syntagmatic variability, finally, does not seem to apply, as the fixed positon that the quantifier has with respect to the noun it combines with has remained unchanged from the partitive noun + postmodifier construction.

Starting from the assertion that it is not individual items that are the proper domain of grammaticalization, but constructions (i.e. elements in context) (see Himmelmann 2004: 31), Himmelmann proposes a different set of grammaticalization criteria involving three types of context-expansion: host-class expansion (i.e. the class of elements a grammaticalizing form is in construction with may be expanded), syntactic context expansion (i.e. extension of a grammaticalizing form to more syntactic contexts), and semantic-pragmatic expansion (i.e. a grammaticalizing form will develop new heterosemies) (see Himmelmann 2004: 32; Traugott and Trousdale 2013: 107). Before applying Himmelmann's criteria to a lot of, I will first discuss the example Himmelmann provides himself, which is that of the grammaticalization of demonstrative to definite article (or rather, DEM + NOUN > ART + NOUN). 
1. host-class expansion: when demonstratives are grammaticalized to articles, they no longer only combine with nouns that combine with demonstratives (e.g. common nouns) but also with proper nouns (e.g. die Vera in German) and nouns designating unique entities (the moon, the sky)

2. syntactic context expansion: during grammaticalization, the use of articles expands from core argument position to peripheral argument position (e.g. adpositional expressions as in He saw me in the room)

3. semantic-pragmatic context expansion: articles expand from deictic reference to associative anaphoric use (where demonstratives would be awkward) (e.g. in the context of a wedding, the bride can be introduced using the definite article; the demonstrative this bride would be awkward here).

As can be seen, the expansion criteria Himmelmann proposes are not necessarily restricted to linguistic elements that are typically associated with the expansion view (such as discourse markers): the grammaticalization shift he describes can easily be accommodated by the reduction view on grammaticalization; that is, it is also perfectly compatible with Lehmann's paradigmatic criteria. In particular, the change from the Old English demonstrative se (singular, nominative, masculine) to the Present-day English definite article the instantiates (i) loss of phonetic integrity (/se/ > /ðə/ involves a change from a peripheral vowel /e/ to the central vowel /ə/) as well as semantic integrity (loss of deictic meaning); (ii) paradigmatization, with a member belonging to the (relatively cohesive) paradigm of determiners entering the highly cohesive paradigm of definite articles (it consists of one member only); (iii) loss of paradigmatic variability or obligatorification, in that the is required with a noun for definite reference. Lehmann's syntagmatic criteria apply less successfully: (iv) in English, the demonstrative as well as the definite article operate at NP-level; therefore the article does not show reduction of syntactic scope vis-à-vis the demonstrative (in the North Germanic languages, however, the determiner is a suffix to the noun, and therefore operates at the more restricted $\mathrm{N}$-level); (v) similarly, the degree of bonding/coalescence does not decrease in the shift from demonstrative to definite article (again, in the North Germanic languages, the definite article, suffixed to the noun, does show a higher degree of bonding); (vi) the demonstrative and the definite article exhibit the same degree of syntagmatic variability (or fixation), so this criterion does not apply.

The grammaticalization of the size/partitive noun a lot [of $+\mathrm{N}$ ] into the quantifier a lot of/lots of/lotsa, described as an example of Lehmann's reduction view above, can also be described in terms of Himmelmann's expansion criteria. First, the shift from partitive noun to quantifier is characterized by host-class expansion: from lot referring to 'a unit that is part of a larger whole' (as in a lot of land), it shifted to 'unit consisting of several members' (as in a lot of sheep), and 
finally to a 'quantity meaning', where it first combined with concrete nouns only (a lot of people) and then extended its collocational range to abstract nouns as well (a lot of time), and even gerunds (a lot of driving) (see Traugott and Trousdale 2013: 24-25, 115). Syntactic context-expansion is seen from the fact that lots is no longer restricted to the [quantifier $+\mathrm{N}$ ] structure, but it can also expand to adverbial use (as in I received lots; He worked lots) or be used as a degree expression with adjectives (e.g. a lot harder). Finally, semantic-pragmatic expansion is attested by the shift from partitive noun over 'unit consisting of several members' to quantifier.

Himmelmann's expansion criteria are not as distinct from Lehmann's reduction criteria as first meets the eye. As Traugott and Trousdale (2013: 109) point out, "many aspects of GE [i.e. grammaticalization as expansion] follow from GR [i.e., grammaticalization as reduction] factors"; in that respect, the two views on grammaticalization can be thought of as complementary, or two sides of the same coin. Consider a lot of again. The semantic change in the grammaticalization of $a$ lot $[o f+\mathrm{N}]$ is not just a matter of loss of semantic integrity: admittedly, a lot does lose its partitive meaning, and the item becomes more abstract, but at the same time it acquires a new, grammatical (or procedural, see Traugott and Trousdale 2013: $12-13$ ) meaning of quantification. ${ }^{4}$ The more abstract, procedural nature of this quantifier meaning, then, allows a lot of to extend its collocational range as well as its potential to be used in more syntactic contexts: a general 'quantifier' meaning is not necessarily restricted to combining with a $\mathrm{N}$, but may also be used in new syntactic slots, such as the adverbial slot. Host-class expansion and syntactic context expansion as well can be seen as the outcome of Lehmann's criteria of paradigmaticity and paradigmatic variability. Indeed, to the extent that a lot of/lots of/lotsa becomes part of more cohesive, functionally homogeneous paradigm and becomes more obligatory (i.e. sees its paradigmatic variability reduced), it is likely to also expand its collocational potential.

\section{Lehmann and Himmelmann compared: in fact}

The discussion of the grammaticalization of the Old English demonstrative se to Present-day English definite article the and of the partitive noun a lot to quantifier has shown that items that can be accounted for from the perspective of

4 What underlies this semantic shift is invited inferencing (see Traugott and Dasher 2002). 
Lehmann's (reduction) characteristics (typically the paradigmatic parameters) can also be accounted for in terms of Himmelmann's expansion view. This is, however, not necessarily the case the other way around. The grammaticalization of discourse markers, for instance, which is well served by an account in terms of Himmelmann's expansion criteria does not fare so well under the reduction perspective. Except for paradigmaticization, fixation, and (to some extent) coalescence/bonding, it is questionable whether Lehmann's other parameters apply; conversely, Himmelmann's expansion criteria apply. Consider in this respect the development of in fact, as presented in detail in Traugott $(1997,1999)$ and in Traugott and Dasher (2002). In fact shows a change from a full lexical noun in a PP (see (1)) to Manner Adverb (or VAdv in Traugott's 1999 terminology) (see (2)) to Sentence adverb emphasizing contrast (see (3)) to Discourse Marker expressing "the speaker's attitude to the appropriateness of the discourse itself" (Traugott and Dasher 2002: 168) (see (4)).

(1) A sort of naughty persons ... whom we have apprehended in the fact. [example taken from Traugott 1999: 184]

(2) But it is evident in fact and experience that there is no universal Judge ... [example taken from Traugott and Dasher 2002: 166]

(3) Every particle eludes the grasp by a new fraction, like quicksilver, when we endeavor to seize it. But as in fact there must be something which terminates the idea of every finite quantity ... [example taken from Traugott 1997: 10]

(4) Thus in various ways ethical questions lead inevitably to psychological discussions; in fact, we may say that all important ethical notions are also psychological. [example taken from Traugott and Dasher 2002: 168]

Examples (1)-(4) clearly show that the replacement of the lexical meaning of in fact in (1) and (2) by the adversative meaning in (3) and (4) cannot be sufficiently captured in terms of loss of semantic integrity; while the meaning of in fact in (3) and (4) is indeed more abstract, it is a different meaning (which also manifests the speaker's subjectivity). Loss of paradigmatic variability does not hold either as the paradigm of discourse markers has increased over time (largely similar variants to in fact are indeed and actually). Nor does scope reduction, as discourse markers have much larger scope than manner adverbs: the former has scope over the preceding and following discourse, while the scope of a manner adverbial is only the VP it combines with. The parameters that do hold are paradigmaticization (in fact is recruited into the coherent, relatively small set of discourse markers), coalescence (because in fact is, on the whole, not broken up by intervening material), and fixation (as a discourse marker, in fact prefers a position where it can have scope over the previous sentence(s) as well as the upcoming sentence(s) - often this is in clause-initial position). 
The development of in fact is served better by Himmelmann's expansion criteria. The semantic change illustrated in (1)-(4) is obviously in line with 'semantic-pragmatic expansion', and the use of in fact as a sentence adverb and as a discourse marker illustrate syntactic expansion with respect to in fact's lexical use in a PP or as a manner adverbial.

\section{Grammatical constructionalization}

In recent years, an increasing number of scholars (Trousdale 2012; Colleman 2015; Traugott 2015) have proposed that grammaticalization can be viewed as a type of constructionalization (alongside lexical constructionalization), thus integrating grammaticalization into Construction Grammar (as initiated by Goldberg 1995, 2006). ${ }^{5}$ Construction Grammar holds that linguistic units are pairings of form/structure and meaning and that these pairings are organized in hierarchically ordered networks (comprising different levels of schematization). Grammatical constructionalization, then, is the creation of a new form-new meaning combination, and it is typically accompanied by changes in the degree of schematicity, productivity, and compositionality (see Traugott and Trousdale 2013: 22, 113-122). A grammaticalizing construction may become schematic or abstract either because it participates in and becomes a "better member" of an abstract schema or because the schema in which the construction participates in expands itself, coming to have more members (see Traugott and Trousdale 2013: 116). A grammaticalizing construction may become more productive because (i) it is used with a larger number of collocates and (ii) its token frequency increases (Traugott and Trousdale 2013: 114). Finally, a grammaticalizing construction may become less compositional in that "the transparency of the match between the meaning of its parts and the form/syntax" decreases (Traugott and Trousdale 2013: 121).

In the following paragraphs, it is shown that the framework of grammatical constructionalization may accommodate grammaticalizating forms compatible with the reduction approach (a lot of) as well as forms favoring Himmelmann's context-expansion approach (discourse markers). First, the change exhibited by a lot of in There is a lot of land for sale vs. They own a lot of land constitutes a case

5 Grammaticalization can also be accommodated within the notion of "constructional change", as presented in Hilpert $(2013,2014,2018)$. I have in this paper opted to focus on its relation with Traugott and Trousdale’s (2013) “constructionalization”. 
of grammatical constructionalization: the constituent structure which changes from [a lot [of land]] to [[a lot of] land] is accompanied by a semantic change from partitive to quantifier meaning. The creation of this new form-meaning unit co-occurs with:

1. Increase in schematicity. (i) The use of lot in a quantifier construction is more schematic, or abstract, than that of the lexical noun lot, in that it loses its specific, partitive meaning in favor of a more general quantitative meaning (as in a lot of work) as well as a degree meaning (as in a lot harder); it is "gradually assigned more prototypical features of the [schema] into which [it has] been recruited" (Traugott and Trousdale 2013: 117), as its behavior comes to resemble that of the older quantifiers much/many, which can also be used in degree expressions. (ii) As a lot of constructionalizes, it comes to coexist with other quantifying or degree expressions (e.g. the older much/many) thereby expanding the abstract quantifier and degree constructions.

2. Increase in productivity. As a lot of grammaticalizes, the type of items it combines with becomes increasingly diversified (from nouns compatible with partitive meaning to mass nouns); in addition, its token frequency has been shown to increase (see Brems 2011, 2012). Note that, along with a lot of, a number of other periphrastic quantifiers have come into the language such as a heap of, a bunch of, a load of (Brems 2010, 2011, 2012), increasing the type frequency of the more schematic category of quantifiers.

3. Decrease in compositionality. At the time of the shift from partitive to quantifier meaning, compositionality is lost, in that the quantifier meaning no longer matches the syntactic Head-Modifier structure; furthermore, the meaning of the quantifier "is not strictly derivable from its parts" (Traugott and Trousdale 2013: 121).

Grammaticalizing forms such as discourse markers, which favor Himmelmann's context-expansion approach, can also be easily accommodated by the constructionalization view. Consider in fact again. The change exhibited by in fact in example (5), repeated from (1), vs. example (6) constitutes a case of grammatical constructionalization.

(5) A sort of naughty persons ... whom we have apprehended in the fact.

(6) I should not have used the expression. In fact, it does not concern you - it only concerns myself. [example taken from Traugott and Dasher 2002: 168]

The different structural status of in fact, from a PP with adverbial function to a discourse marker acting as a pivot between the preceding and the following discourse, is accompanied by a semantic change (from a lexical reading of in fact to 
a contrastive reading in which the speaker corrects their previous discourse). The creation of this new form-meaning unit co-occurs with:

1. Increase in schematicity. The meaning of fact in the sentence adverbial and discourse maker use of in fact is more schematic than that of the lexical noun fact, in that it acquires an epistemic adversative and then discoursestructuring function. Furthermore, as in fact constructionalizes, it comes to coexist with other discourse makers with a similar function such as indeed and actually, thereby expanding this schematic discourse marker category.

2. Increase in productivity. As in fact grammaticalizes, its collocational range becomes increasingly diversified (in fact combines successively with verbs > sentences $>$ discourse fragments).

3. Decrease in compositionality. At the time of the shift towards a procedural meaning, compositionality is lost: the sentence adverbial and discourse structuring function of in fact cannot be derived from the sum of its parts.

The preceding discussion has shown that grammaticalizing forms that are typically characterized in terms of Lehmann's reduction view and/or Himmelmann's expansion criteria can also fruitfully be described in terms of the grammatical constructionalization approach proposed by Traugott and Trousdale (2013). Again, this suggests that what look like distinct sets of grammaticalization criteria may not be as distinct as first meets the eye. By way of summary, I examine how these characterizing features of grammatical constructionalization correlate with Lehmann's and Himmelmann's parameters. First of all, the creation of a pairing of a new form and a new meaning, which is the defining feature of grammatical constructionalization, can be linked up with Lehmann's paradigmatization. Although paradigmatization is not concerned with the semantics of the grammaticalizing item, it does single out that grammaticalization involves a shift to a new syntactic category; in this respect, it can be said to pair up, albeit only partly, with the constructional grammaticalization approach. As well, Himmelmann's semantic-pragmatic expansion involves a change that may not only lead to a form's new meaning but may also describe subsequent semantic changes; syntactic context expansion is a process that typically occurs after the new form - new meaning pairing has been created. Second, increasing schematicity starts off with Lehmann's loss of semantic integrity (bleaching), but finds a more comprehensive equivalent in Himmelmann's semantic-pragmatic expansion. Increasing productivity, then, most naturally links up with Himmelmann's host-class expansion (see also Traugott and Trousdale 2013: 114). Decrease in compositionality, finally, correlates with Lehmann's semantic bleaching and with the initial stages of Himmelmann's semantic-pragmatic expansion: it is likely that the attrition of semantic features of a form may lead to the loss of compositionality of the construction the form is part of. 


\section{Summing up}

The discussion of the various sets of grammaticalization parameters has shown, as Traugott and Trousdale (2013: 123) point out, "that the approaches are far from orthogonal. Rather, the factors considered intertwine in change". In the constructional grammaticalization approach, constructionalization itself can be preceded by prior constructional changes and can be followed by subsequent constructional changes. It is in these prior and subsequent changes that Lehmann and Himmelmann's criteria play a role. In particular, it is suggested that "some semantic attrition and loss of compositionality and morphosyntactic fixing may precede ... constructionalization” (Traugott and Trousdale 2013: 124) and that "grammatical constructionalization "is followed by increases in ... typeproductivity" (i.e. host-class expansion). Syntactic context expansion will also typically follow constructionalization as well as decrease of phonetic integrity and increased obligatorification (or loss of paradigmatic variability). The fact that the grammatical constructionalization approach thus adds a chronology to Lehmann's and/or Himmelmann's criteria adds a valuable dimension to grammaticalization research that is certainly worth further investigation.

\section{References}

Barðdal, Jóhanna, Elena Smirnova, Lotte Sommerer \& Spike Gildea (eds.). 2015. Diachronic Construction Grammar. Amsterdam: John Benjamins.

Bisang, Walter, Nikolaus P. Himmelmann \& Björn Wiemer (eds.). 2004. What makes grammaticalization: A look from its fringes and its components. Berlin: Mouton de Gruyter.

Breban, Tine \& Svenja Kranich (eds.). 2015. What happens after grammaticalization? Secondary grammaticalization and other late stage processes. Special issue of Language Sciences 47.

Brems, Lieselotte. 2010. Size noun constructions as collocationally constrained constructions: Lexical and grammaticalized uses. English Language and Linguistics 14. 83-109.

Brems, Lieselotte. 2011. Layering of size and type noun constructions in English. Berlin: De Gruyter Mouton.

Brems, Lieselotte. 2012. The establishment of quantifier constructions for size nouns: A diachronic study of heap(s) and lot(s). Journal of Historical Pragmatics 13. 202-231.

Brinton, Laurel. 1996. Pragmatic markers in English: Grammaticalization and discourse function. Berlin: Mouton de Gruyter.

Bybee, Joan, Revere Perkins \& William Pagliuca. 1994. The evolution of grammar: Tense, aspect, and modality in the languages of the world. Chicago: The University of Chicago Press.

Campbell, Lyle (ed.). 2001. Grammaticalization: A critical assessment. Special issue of Language Sciences 23(2-3).

Clackson, James. 2016. Latin as a source for the Romance languages. In Adam Ledgeway \& Martin Maiden (eds.), The Oxford guide to the Romance languages, 3-13. Oxford: Oxford University Press. 
Colleman, Timothy. 2015. Constructionalization and post-constructionalization: The constructional semantics of the Dutch krijgen-passive from a diachronic perspective In Jóhanna Barðdal, Elena Smirnova, Lotte Sommerer \& Spike Gildea (eds.), Diachronic Construction Grammar, 213-255. Amsterdam: John Benjamins.

Coussé, Evie, Peter Andersson \& Joel Olofsson (eds.). 2018. Grammaticalization meets Construction Grammar. Amsterdam: John Benjamins.

Davidse, Kristin, Tine Breban, Lieselotte Brems \& Tanja Mortelmans (eds.). 2012. Grammaticalization and language change: New reflections. Amsterdam: John Benjamins.

Fischer, Olga. 2000. Grammaticalisation: Unidirectional, non-reversable? The case of to before the infinitive in English. In Olga Fischer, Anette Rosenbach \& Dieter Stein (eds.), Pathways of change: Grammaticalization in English, 149-169. Amsterdam: John Benjamins.

Fischer, Olga, Muriel Norde \& Harry Perridon (eds.). 2004. Up and down the cline: The nature of grammaticalization. Amsterdam: John Benjamins.

Fischer, Olga, Anette Rosenbach \& Dieter Stein (eds.). 2000. Pathways of change: Grammaticalization in English. Amsterdam: John Benjamins.

Goldberg, Adele. 1995. Constructions: A Construction Grammar approach to argument structure. Chicago, IL: The University of Chicago Press.

Goldberg, Adele. 2006. Constructions at work. Oxford: Oxford University Press.

Hancil, Sylvie. 2014. The final particle but in British English: An instance of cooptation and grammaticalization at work. In Sylvie Hancil \& Ekkehard König (eds.), Grammaticalization: Theory and data, 235-256. Amsterdam: John Benjamins.

Hancil, Sylvie, Tine Breban \& José Vicente Lozano (eds.). forthc. New trends on grammaticalization and language change. Amsterdam: John Benjamins.

Hancil, Sylvie \& Ekkehard König (eds.). 2014. Grammaticalization: Theory and data. Amsterdam: John Benjamins.

Haspelmath, Martin. 1989. From purposive to infinitive: A universal path of grammaticalization. Folia Linguistica Historica 10. 287-310.

Haspelmath. 2004. On directionality in language change with particular reference to grammaticalization. In Olga Fischer, Muriel Norde \& Harry Perridon (eds.), Up and down the cline: The nature of grammaticalization, 17-44. Amsterdam: John Benjamins.

Heine, Bernd, Ulrike Claudi \& Friederike Hünnemeyer. 1991. Grammaticalization: A conceptual framework. Chicago: University of Chicago Press.

Heine, Bernd \& Tania Kuteva. 2002. World lexicon of grammaticalization. Cambridge: Cambridge University Press.

Hilpert, Martin. 2013. Constructional change in English: Developments in allomorphy, word formation, and syntax. Cambridge: Cambridge University Press.

Hilpert, Martin. 2014. Construction Grammar and its application to English. Edinburgh: Edinburgh University Press.

Hilpert, Martin. 2018. Three open questions in diachronic construction grammar. In Evie Coussé, Peter Andersson \& Joel Olofsson (eds.), Grammaticalization meets Construction Grammar, 21-39. Amsterdam: John Benjamins.

Himmelmann, Nikolaus P. 2004. Lexicalization and grammaticalization: Opposite or orthogonal? In Walter Bisang, Nikolaus Himmelmann \& Björn Wiemer (eds.), What makes grammaticalization: A look from its fringes and its components, 21-42. Berlin: Mouton de Gruyter.

Hopper, Paul J. \& Elizabeth Closs Traugott. 2003 [1993]. Grammaticalization, 2nd edition. Cambridge: Cambridge University Press. 
Jucker, Andreas. 1997. The discourse marker well in the history of English. English Language and Linguistics 1. 91-110.

Lehmann, Christian. 2004. Theory and method in grammaticalization. In Gabriele Diewald (ed.), Grammatikalisierung. Special issue of Zeitschrift für Germanistische Linguistik 32. 152-187.

Lehmann, Christian. 2015 [1995]. Thoughts on grammaticalization, 3rd edition. Berlin: Language Science Press. 10.17169/langsci.b88.98.

López-Couso, María José \& Elena Seoane (eds.). 2008. Rethinking grammaticalization: New perspectives. Amsterdam: John Benjamins.

Narrog, Heiko \& Bernd Heine. 2011. The Oxford handbook of grammaticalization. Oxford: Oxford University Press.

Norde, Muriel, Karen Beijering \& Alexandra Lenz (eds.). 2013. Current trends in grammaticalization research. Special issue of Language Sciences 36.

Ramat, Anna Giacalone \& Paul J. Hopper (eds.). 1998. The limits of grammaticalization. Amsterdam: John Benjamins.

Roberts, Ian \& Anna Roussou. 2003. Syntactic change. Cambridge: Cambridge University Press.

Seoane, Elena \& María José López-Couso (eds.). 2008. Theoretical and empirical issues in grammaticalization. Amsterdam: John Benjamins.

Smith, Andrew D.M., Graeme Trousdale \& Richard Waltereit (eds.). 2015. New directions in grammaticalization research. Amsterdam: John Benjamins.

Thompson, Sandra \& Anthony Mulac. 1991. A quantitative perspective on the grammaticalization of epistemic parentheticals in English. In Elizabeth Traugott \& Bernd Heine (eds.). Approaches to grammaticalization, Volume II, 313-329.

Traugott, Elizabeth. 1989. On the rise of epistemic meanings in English: An example of subjectification in semantic change. Language 57. 33-65.

Traugott, Elizabeth. 1997. The role of the development of discourse markers in a theory of grammaticalization. Paper presented at the International Conference of Historical Linguistics XII, Manchester. Unpublished paper, available at https://www.researchgate. net/publication/228691469_The_role_of_discourse_markers_in_a_theory_of_ grammaticalization.

Traugott, Elizabeth. 1999. The rhetoric of counter-expectation in semantic change: A study in subjectification. In Andreas Blank \& Peter Koch (eds.), Historical semantics and cognition, 177-196. Berlin: Mouton de Gruyter.

Traugott, Elizabeth. 2003. From subjectification to intersubjectification. In Raymond Hickey (ed.), Motives for language change, 124-139. Cambridge: Cambridge University Press.

Traugott, Elizabeth 2010a. Grammaticalization. In Silvia Luraghi \& Vit Bubenik (eds.), Continuum companion to historical linguistics, 271-285. London: Continuum.

Traugott, Elizabeth. 2010b. (Inter)subjectivity and (inter)subjectification: A reassessment. In Kristin Davidse, Lieven Vandelanotte \& Hubert Cuyckens (eds.), Subjectification, intersubjectification and grammaticalization, 29-71. Berlin: De Gruyter Mouton.

Traugott, Elizabeth. 2015. Toward a coherent account of grammatical constructionalization. Jóhanna Barðdal, Elena Smirnova, Lotte Sommerer \& Spike Gildea (eds.), Diachronic Construction Grammar, 51-79. Amsterdam: John Benjamins.

Traugott, Elizabeth \& Richard Dasher. 2002. Regularity in semantic change. Cambridge: Cambridge University Press.

Traugott, Elizabeth \& Bernd Heine (eds.). 1991. Approaches to grammaticalization, 2 Volumes. Amsterdam: John Benjamins. 
Traugott, Elizabeth \& Ekkehard König. 1991. The semantics-pragmatics of grammaticalization revisited. In Elizabeth Traugott \& Bernd Heine (eds.), Approaches to grammaticalization, Volume 1, 189-218. Amsterdam: John Benjamins.

Traugott, Elizabeth \& Graeme Trousdale (eds.). 2010. Gradience, gradualness and grammaticalization. Amsterdam: John Benjamins.

Traugott, Elizabeth \& Graeme Trousdale. 2013. Constructionalization and constructional change. Oxford: Oxford University Press.

Trousdale, Graeme. 2012. Grammaticalization, constructions, and the grammaticalization of constructions. In Kristin Davidse, Tine Breban, Lieselotte Brems \& Tanja Mortelmans (eds.), Grammaticalization and language change: New reflections, 167-198. Amsterdam: John Benjamins.

Van Gelderen, Ellie. 2004. Grammaticalization as economy. Amsterdam: John Benjamins.

Van linden, An, Jean-Christophe Verstraete \& Kristin Davidse (eds.). 2010. Formal evidence in grammaticalization research. Amsterdam: John Benjamins.

Von Mengden, Ferdinand \& Horst Simon (eds). 2014. What is it then, this grammaticalization? Special Issue of Folia Linguistica 48(2).

Wischer, Ilse \& Gabriele Diewald (eds.). 2002. New reflections on grammaticalization. Amsterdam: John Benjamins. 